Jurnal Pemikiran Sosiologi Volume 6 No. 1, Januari 2019

Pengantar Redaksi:

\title{
“Dekolonisasi Ilmu Sosial Humaniora: dari Pengetahuan Lokal ke Pemberdayaan Masyarakat”
}

Jurnal Pemikiran Sosiologi Volume 6 Nomor 1, Januari - Juli 2019 menghadirkan penerbitan yang bertema 'Dekolonisasi Ilmu Sosial Humaniora: dari Pengetahuan Lokal ke Pemberdayaan Masyarakat'. Penerbitan ini merupakan bagian dari upaya untuk mengidentifikasi tema-tema pertautan kajian pascakolonial (postcolonial study) dengan Sosiologi yang secara spesifik menunjuk pada konteks sejarah perkembangan masyarakat yang spesifik di Indonesia termasuk bagaimana ilmu-ilmu sosial humaniora berperan dalam upaya untuk menjadi perangkat pengetahuan yang membebaskan masyarakat dari belenggu penindasan kemanusiaan. Secara khusus kajian pascakolonial menawarkan suatu formulasi untuk membebaskan diri dari warisan-warisan pengetahuan yang dilembagakan melalui praktik eksploitasi dan penindasan dalam sejarah kolonialisme.

Upaya inilah yang dikenal sebagai 'dekolonisasi' - yaitu bagaimana suatu masyarakat mampu untuk membebaskan dirinya dari belenggu penindasan dan eksploitasi kemanusiaan sehingga mampu untuk menentukan arah perubahan sosial, ekonomi, politik dan budaya bagi dirinya sendiri. Dengan kata lain, dekolonisasi adalah suatu upaya mencapai kemandirian yang bermartabat bagi suatu masyarakat atau bahkan suatu komunitas yang lebih besar seperti negara-bangsa (nation-state). Selama ini kajian pascakolonial bahkan pascakolonialisme (postcolonialism) yang menjadi basis ideologis intelektual untuk mengupayakan dekolonisasi pengetahuan bagi masyarakat di wilayah-wilayah bekas jajahan khususnya kekuasaan kolonial Eropa - lebih banyak dibahas dalam disiplin ilmu humaniora khususnya ilmu-ilmu budaya, ketimbang ilmu sosial, termasuk Sosiologi. Padahal kontradiksi dalam masyarakat moderen yang kapitalis justru tetap melanggengkan kuasa pengetahuan kolonial yang mengeksploitasi kemanusiaan, misalnya di dalam praktik kapitalisme neoliberal yang membolehkan eksploitasi sumberdaya alam, bahkan relasi kemanusiaan termasuk di dalamnya norma-nilai, sistem kepercayaan dan tradisi untuk dimaksimalkan sebagai 'komoditas' yang dalam kenyataannya hanya menguntungkan segelintir orang saja. Artinya, kajian pascakolonial berkenaan pula dengan tema-tema sentral di dalam Sosiologi seperti sejarah modernitas, pembentukan kelas-kelas sosial, perkembangan sejarah dunia termasuk globalisasi, dan pelembagaan ilmu pengetahuan yang diwariskan dan dilembagakan secara moderen.

Dewan Redaksi Jurnal Pemikiran Sosiologi (JPS) yang didukung penerbit yakni Departemen Sosiologi, Fisipol UGM menghadirkan pembahasan tema yang mempertautkan kajian pascakolonial dengan Sosiologi melalui dua edisi penerbitan Volume 6 di tahun 2019 ini. Dalam edisi kali, JPS Vol 6 (1) menghadirkan enam artikel terpilih yang secara keseluruhan membahas tentang bagaimana pengetahuan yang dipraktikkan oleh masyarakat - termasuk yang selama ini didefinisikan sebagai bentuk 'pengetahuan lokal' - menjadi upaya untuk mencari jalan bagi transformasi sosial masyarakat yang lebih berkeadilan, dalam pengertian untuk membebaskan masyarakat dari belenggu kemiskinan, ketidakberdayaan, dan posisi tawar di dalam relasi kelas sosial yang tidak berimbang. 
Jurnal Pemikiran Sosiologi Volume 6 No. 1, Januari 2019

Artikel pertama ditulis oleh Rusydan Fathy mengenai modal sosial sebagai suatu alat analisis kritis yang dapat digunakan untuk memberdayakan masyarakat melalui pembangunan inklusif yang berkelanjutan. Penulis artikel ini menyimpulkan bahwa konsep modal sosial berfungsi sebagai kerangka berpikir yang bermanfaat dalam keberhasilan pembangunan dan perumusan kebijakan khususnya dalam rekayasa sosial yang bersifat inklusif. Artikel kedua ditulis oleh Mohammad Jeffry Maulidi yang memaparkan dengan lugas bagaimana pelekatan identitas Islami (yang merujuk pada nilai dan norma Islam atau syariah) menjadi sistem nilai budaya lokal yang penting bagi masyarakat di pulau Lombok, NTB. Sementara disisi lain pemerintah justru menggiatkan aktivitas perekonomian melalui industri pariwisata bertaraf internasional. Wisata halal dibangun sebagai wujud akomodasi atas pelekatan identitas Islami tetapi hanya mewakili kepentingan yang bersifat pro-bisnis. Artikel ketiga ditulis oleh Roikan yang menjabarkan secara spesifik dinamika kehidupan para kartunis lepas di era budaya siber dimana teknologi digital menjadi tantangan khusus bagi keberlangsungan hidup mereka. Dalam penelitiannya, penulis menemukan bahwa transformasi teknologi digital justru ikut mendorong upaya inovasi dalam proses kreatif bagi para kartunis lepas tersebut. Artikel keempat ditulis oleh Agustinus Gergorius Raja Dasion tentang konflik kepentingan antara negara dan masyarakat Lamalera di NTT terjadi dalam praktik pewacanaan konservasi lingkungan hidup laut (sealife) yaitu konservasi ikan paus. Hal ini dikarenakan berburu ikan paus merupakan tradisi lokal yang memiliki nilai sakral bagi masyarakat setempat. Sementara, konservasi paus yang digalakkan pemerintah membawa kepentingan dunia internasional - dimana terjadi benturan pengetahuan dan pemahaman dalam upaya merawat lingkungan hidup laut termasuk khususnya ikan paus. Berburu ikan paus (whaling) dilakukan masyarakat Lamalera dengan pengetahuan lokal yang tidak mengabaikan keberlangsungan kehidupan di laut, akan tetapi pewacanaan yang digalakkan pemerintah sepertinya mengabaikan realitas itu. Dengan pendekatan analisis wacana, penulis menjelaskan secara kritis bagaimana konflik kepentingan terjadi akibat strategi pewacanaan yang tidak berimbang. Artikel kelima ditulis oleh Nikodemus Niko yang mengkaji kemiskinan yang bersifat multidimensional di kalangan kaum perempuan suku Dayak Benawan, di Kalimantan Barat. Penelitian yang dilakukannya menunjukkan bahwa pelembagaan tradisi terutama dalam pertanian justru menghambat akses pengambilan keputusan baik di dalam keluarga maupun di dalam komunitas bagi kaum perempuan suku Dayak Benawan untuk memperoleh kesejahteraan dan status yang lebih setara. Akibatnya, tradisi lokal justru digunakan untuk menjadi perangkap pengkondisian kemiskinan khususnya bagi kaum perempuan. Narasi-narasi pengkondisian kemiskinan melalui tradisi itulah yang oleh penulis disebut sebagai suatu praktik kolonialisme baru (neocolonialism) - karena masyarakat di Kalimantan Barat kini juga menjadi bagian dari masyarakat global dimana kapitalisme dipraktikkan secara rasional dan meneguhkan sistem eksploitasi seperti di masa kolonial. Artikel keenam ditulis oleh Fred Keith Hutubessy dan Jacob Daan Engel yang secara khusus membahas tentang perkembangan terkini konstruksi identitas kebangsaan orang atau bangsa Papua yang disebut sebagai 'sakralitas-nasionalisme' Papua dan persebaran wacananya melalui pergerakan Aliansi Mahasiswa Papua. Sakralitas nasionalisme Papua dalam pandangan kedua penulis merupakan rasa memiliki (sense of belonging) dimana nasionalisme bagi orang atau bangsa Papua bersifat spesifik - dimana pengalamanan ketertindasan terutama kekerasan yang mengabaikan hak asasi 
Jurnal Pemikiran Sosiologi Volume 6 No. 1, Januari 2019

manusia (HAM) menjadi suatu konstruksi nilai yang penting dan sakral bagi orang Papua sebagai suatu 'bangsa' (nation). Pengalaman ketertindasan yang dirasakan orang Papua berbeda dengan suku-suku atau etnis lainnya di Indonesia, dimana bentuk-bentuk ketertindasan seperti di masa kolonial hingga kini justru masih berlangsung di Papua dan terhadap orang Papua. Bukan hanya pada eksploitasi sumberdaya alam semata, tetapi juga pada bentuk-bentuk pelanggaran HAM, pelekatan stigma dan stereotipe yang negatif seperti 'bangsa primitif' - yang berakar pada sistem rasisme. Dalam penelitiannya, kedua penulis menunjukkan bahwa pergerakan mahasiswa Papua melalui Aliansi Mahasiswa Papua di Yogyakarta - menunjukkan bahwa upaya mendesiminasikan (persebaran wacana) sakralitas nasionalisme Papua justru dianggap sebagai suatu upaya memobilisasi gerakan separatis yang melawan negara atau otoritas pemerintahan Republik Indonesia. Padahal pergerakan mahasiswa Papua tersebut bersifat inklusif yang juga melibatkan elemen-elemen pergerakan pro-demokrasi lainnya di Indonesia yang mengekspresikan keprihatinan bersama atas kondisi hak asasi manusia di Indonesia. Dalam konteks inilah, kedua penulis menjelaskan bagaimana 'nasionalisme-ganda' bagi orang Papua berlangsung. Dengan kata lain, represi kekuasaan di Indonesia atas ekspresi 'sakralitas nasionalisme Papua' justru melanggengkan penindasan seperti yang dilakukan oleh penguasa di masa kolonial terhadap bangsa Indonesia sendiri.

Demikianlah keenam artikel pilihan yang kami sajikan dalam edisi penerbitan Jurnal Pemikiran Sosiologi Volume 6 No 1 tahun 2019 ini. Penerbitan edisi ini merupakan upaya kami untuk berkontribusi pada tantangan mendefinisikan kajian pascakolonial dan kaitannya dengan ilmu sosial-humaniora khususnya Sosiologi di Indonesia. Semoga sajian penerbitan ini bermanfaat dan menginspirasi.

Salam,

\section{Dewan Redaksi Jurnal Pemikiran Sosiologi.}

